\title{
Production of polyclonal antibodies against Turkey FMDV strains
}

\author{
Beyhan Sareyyüpoğlu' ${ }^{1}$ \\ ${ }^{7}$ FMD (Sap) Institute, Çankaya, Ankara, Turkey
}

Geliş Tarihi / Received: 18.12.2020, Kabul Tarihi / Accepted: 03.05.2021

\begin{abstract}
Antibodies (Abs) have been one of the most important tools in diagnostic laboratories. Many diagnostic techniques such as Enzyme-Linked Immuno-Sorbent Assays (ELISA), immunofluorescence, Ab-microarray platforms, immunoblots, X-ray crystallography require the Abs. ELISA is an assay method that is among the basic tests using antibodies for the serology of Foot and Mouth Disease (FMDV). This method requires polyclonal or monoclonal antibodies to detect FMDV antigen or antibodies. For this purpose, solid-phase competitive ELISA (SPCE) or liquid phase blocking ELISA (LPBE) and non-structural protein (NSP) ELISA are used. SPCE and LPBE have mainly used FMDV structural protein antibody (SP-Ab) detection.

In this study, it was aimed to produce a polyclonal Ab against FMDV ANep84 (Genotype VII) and OTUR07 (OPanAsia II), ATUR11 (A Iran05) strains for LPBE, FMDV SP-Ab detection. For this purpose, four guinea pigs and six rabbits were used for each serotype of FMDV. After producing Abs, checkerboard ELISA titration was performed to determine the optimal test dilution of Abs. Backgrounds, cross-reactions against three strains of FMDV were also checked. In conclusion, polyclonal Abs were produced against FMDV ANep84 (Genotype VII) and O Tur07 (O Pan Asia II), ATUR11 (A Iran05) strains, and standardized for LPBE test.
\end{abstract}

Keywords: ELISA, FMD, polyclonal antibodies

\section{Türkiye'de Şap virüsü şuşlarına karşı poliklonal antikor üretimi}

Özet: Antikorlar tanı laboratuvarlarında daima önemli bir yer tutmaktadır. Enzim işaretli bağışıklık testleri (ELıSA), immunofloresan, antikor-mikroarray platformları, immunoblotlar, X-ışını kristalografisi gibi birçok tanı tekniği kullanımı antikorların varlığını gerektirir. Şap hastalığı serolojisinde antikorların kullanıldığı temel test ELISA'dır. ELISA testleri şap virusu antijenini veya şap virusuna karşı organizmada oluşan antikorları tespit etmek için poliklonal veya monoklonal antikorlara intiyaç duyar. Bu amaçla, solid faz kompetetif ELISA (SPCE) ve likit faz bloking ELISA (LPBE) ve yapısal olmayan (NSP) ELISA yöntemleri kullanılır. Şap virusunun yapısal proteinlerine (SP) karşı oluşan antikorları tespit etmek için ise SPCE ve LPBE testleri kullanılır.

Bu çalışmada, ANep84 (genotip VII), O TUR07 (O Pan Asia II), ATUR11 (A Iran05) şap virusu suşlarına karşı LPBE testinde kullanılmak üzere poliklonal antikor üretmek amaçlandı. Bu amaçla, her bir FMDV serotipi için dört adet kobay ve altı adet tavşan kullanıldı. Antikorlar üretildikten sonra, dama tahtası (checkerboard ELISA titration) testi ile üretimi yapılan poliklonal antikorlar için optimal dilusyonlar belirlendi. Şap virusu suşlarına karşı oluşabilecek çapraz reaksiyonlar ve background reaksiyonları kontrol edildi. Sonuç olarak, bu çalışmada şap virusu ANep84 (genotip VII) ve O Tur07 (O Pan Asia II), ATUR11 (Alran05) suşlarına karşı poliklonal antikorlar üretildi ve LPBE testi için standardizasyonları yapıldı.

Anahtar kelimeler: ELISA, poliklonal antikorlar, şap hastalığı

\section{Introduction}

FMD is a highly contagious viral disease which affects the cloven-hooved animals causing serious economic losses (Fry et al. 2005; Diaz San Segundo et al. 2017). FMDV is a small positive-sense RNA virus. The capsid of the FMDV consists of a combination of protomers and pentamers to form an icosahedral structure (Jamal and Belsham 2013).

Serological tests for FMDV began to gain momentum with the 1980s via ELISA (Hamblin et al. 1986). For this aim, OIE (World Organisation for Animal Health) defined two ELISAs for SP-Ab detection; solid-phase competitive ELISA (SPCE) or liquid phase blocking ELISA (LPBE) (Hamblin et al. 1986; Sorensen et al. 1998; Anonymus 2019). These tests are used to determine an FMD infected animal and/or a vaccinated animal via the polyclonal or monoclonal Abs. Polyclonal Abs are used in the $\angle P B E$. It requires two types of $A b s$; one of them is the capturing $A b$ produced in rabbits and another one is the detecting $A b$ produced in guinea pigs. 
The main beneficial properties of polyclonal Abs are their clonal and biophysical diversity. Its' poly-clonality allows the binding of multiple antigenic determinants. Its' biophysical diversity allows greater stability when the environmental challenges may cause inactivation of antibody, lability, or precipitation of other forms of antibodies (Harlow and Lane 1988; Leenars et al.1999; Leenars and Hendriksen 2005; Lipman et al. 2005; Voskuil 2014; Ascoli and Aggeler 2018). Cross-reactions and non-specific backgrounds are two main difficulties in the usage of the polyclonal Abs for the serological tests. To minimize the cross-reaction problem, purification of Abs can be tried. However, $\mathrm{Ab}$ purification is a costly and labor-consuming process (Low et al. 2006). The background problem can be mitigated by further diluting the antibody or blocking it. Thus, the lower affinity interactions will not work with lower Ab concentrations. Proper blocking conditions can help to prevent low-affinity Ab interactions (Voskuil 2014).

The purpose of the study is to produce polyclonal Abs (capturing and detecting Abs for FMDV Turkey (ANep84 (Genotype VII), OTur07 (O Pan Asia II), ATUR11 (Alran05) FMDV strains and standardize them for LPBE.

\section{Materials and Methods}

Preparation of immunization antigen: $146 \mathrm{~S}$ particles of FMDV strains were used as an immunization antigen. Baby Hamster Kidney (BHK21) cell line was used for virus propagation. After that, a propagated virus was concentrated with poly-ethylene glycol (PEG) and collected by the sucrose density gradient method. The $146 \mathrm{~S}$ content of antigens was determined as described by the method of Barteling and Meloen (Barteling and Meloen 1974).

Calculation of immunization antigen quantity in each dose: For this aim, first, the total animal number defined in the study. Then, antigen quantity determination in each dose. After that, Freund's complete (first immunization) and incomplete (the second immunization adjuvants were added to the antigen stocks respectively. For this purpose, the ( $\mathrm{n} 1$. $v 1=n 2 . v 2$ ) formula was used for the calculation of each animal immunization antigen dose (Zumdahl and De Coste 2009). n1:the antigen quantity of $146 \mathrm{~S}$ particle spectrophotometrically $(\mu \mathrm{g} / \mathrm{ml}), \mathrm{v} 1$ : the required amount of antigen taken from stock antigen solution $(\mathrm{ml}), \mathrm{n} 2$ : the required amount of antigen in a rabbit or a guinea pig dose $(\mu \mathrm{g} / \mathrm{ml})$, it is $20 \mu \mathrm{g} / \mathrm{ml}$ for rabbit and $10 \mu \mathrm{g} / \mathrm{ml}$ for guinea pig v2: the total prepared volume of $146 \mathrm{~S}$ antigen $(\mathrm{ml})$.

Animals: Free ranged guinea pigs (Duncan Hurtley breed, 600 g, 4 months old, female) and rabbits (California breed, $1.5 \mathrm{~kg}, 3$ months month old, female) were used for immunizations, respectively.

Immunization of animals: A total of $0.5 \mathrm{ml}$ antigen and adjuvant were inoculated subcutaneously into the right and left abdomen of rabbit or guinea pig. Detailed information about immunization antigens is shown in Table 1. One month (28 days after the first dose, second dose implemented) apart-double booster immunization schedule was used (Ferris and Donaldson 1984; Have 1984; Harlow and Lane 1988; Lipman et al. 2005). After 15 days after the second immunization, the animals were ceased.

Table 1. Serotype, strain, and $146 \mathrm{~S}$ antigen quantity of immunization antigens

\begin{tabular}{clc}
\hline Serotype Strain & $\begin{array}{c}146 \\
\text { S-spectrophotometric } \\
\text { quantity }\end{array}$ \\
\hline O & O Tur 07 (O PanAsia II) & $250 \mu \mathrm{g} / \mathrm{ml}$ \\
A & ANepal 84 (Genotype VII) & $350 \mu \mathrm{g} / \mathrm{ml}$ \\
A & ATUR11 (A Iran 05) & $690 \mu \mathrm{g} / \mathrm{ml}$ \\
\hline
\end{tabular}

Blood sample collection: After blood centrifugation at $3000 \mathrm{rpm}$ for $10 \mathrm{~min}$, sera were separated. First, each serum was tested with LPBE for titer and then pooled. After that, sera were stored at $-20^{\circ} \mathrm{C}$ until tests. A total of $50 \%$ percent glycerol and $0.002 \%$ sodium azide were added to the sera. The total yielding amount and storage conditions of produced antiserums are shown in the Tables below (Tables 2 and 3).

Table 2. Total yielding amount and storage conditions of capturing (rabbit) Abs

\begin{tabular}{llc}
\hline Serotype/strain & Storage conditions & Total amount \\
\hline O TUR07 & $-80^{\circ} \mathrm{C}$ with sodium azide $0.002 \%$ and $50 \%$ glycerol, $0.5 \mathrm{ml}$ cryotube & $113 \mathrm{ml}$ \\
ATUR11 & $-80^{\circ} \mathrm{C}$ with sodium azide $0.002 \%$ and $50 \%$ glycerol, $0.5 \mathrm{ml}$ cryotube & $140 \mathrm{ml}$ \\
A Nepal84 & $-80^{\circ} \mathrm{C}$ with sodium azide $0,002 \%$ and $50 \%$ glycerol, $0.5 \mathrm{ml}$ cryotube & $110 \mathrm{ml}$ \\
\hline
\end{tabular}


Table 3. Total yielding amount and storage conditions of detecting (guinea pig) Abs

\begin{tabular}{llc}
\hline Serotype/strain & Storage conditions & Total amount \\
\hline O TUR 07 & $-80^{\circ} \mathrm{C}$ with sodium azide $0,002 \%$ and $50 \%$ glycerol, $0.5 \mathrm{ml}$ cryotube & $60 \mathrm{ml}$ \\
A TUR11 & $-80^{\circ} \mathrm{C}$ with sodium azide $0,002 \%$ and $50 \%$ glycerol, $0.5 \mathrm{ml}$ cryotube & $50 \mathrm{ml}$ \\
A Nepal84 & $-80^{\circ} \mathrm{C}$ with sodium azide $0,002 \%$ and $50 \%$ glycerol, $0.5 \mathrm{ml}$ cryotube & $55 \mathrm{ml}$ \\
\hline
\end{tabular}

Standardization of produced polyclonal serum: Checkerboard titration ELISA was performed to determine optimal test dilution of polyclonal Abs (Crowther 2001). For this aim, the rabbit Ab was diluted two-fold from the left to the right line of the ELISA plate starting from the initial dilution at a rate of $1 / 125$. After incubation at $4^{\circ} \mathrm{C}$ overnight, the plate was washed with Dulbecco PBS with six cycles, and the appropriate reference virus with optimal dilution rate is added to all plate wells and kept in the 37 ${ }^{\circ} \mathrm{C}$ incubator for one hour. After washing cycles, the guinea pig $A b$ was diluted two-fold from the upper to the bottom line of the plate starting from the initial dilution at a rate of $1 / 62.5$. After washing cycles, then the conjugate (HRP-labeled polyclonal rabbit anti-guinea pig IgGs, P0141 DAKO) was added to the plate and kept in the $37^{\circ} \mathrm{C}$ incubator for one hour. After washing cycles, the chromogen substrate (OPD) was added. The reaction was stopped by sulphuric acid (1.25 M sulphuric acid) after 15 minutes at room temperature. The colour change was read in the ELISA reader (Versamax, Molecular Devices) at a wavelength of $492 \mathrm{~nm}$.

To control the cross-reaction and backgrounds between the FMDV serotypes, a sandwich ELISA was performed. For this purpose, plates were coated with optimal dilution (well A-D) of capturing rabbit antibodies according to final checkerboard dilution titers of each serotype of FMDV antibodies (1/5000). Then, to check cross-reactions of FMDV OTUR07 with the other FMDV strains (ANepal and ATUR11), optimal dilution of FMDV OTUR07 was added to (well A-B). After that, optimal dilutions of FMDV A TUR11 and FMDV ANepal were added to wells C and $D$, respectively. Similar to the OTUR07 cross reaction study, the same steps were performed to detect cross-reactions of FMDV ATUR11 and ANepal with other FMDV serotypes.11-12 wells were left as a background control well. After one hour at $37^{\circ} \mathrm{C}$ incubation, plate washed, and FMDV detecting antibodies were added to the plate and incubated at the same condition. After washing cycles, the conjugate (DAKO, P0141 rabbit anti guinea pig immunoglobulins/HRP) was added to the plate. After that, the same steps were followed as described above in the checkerboard board ELISA titration.

To reduce nonspecific-cross and background reactions guinea pig serum was blocked with normal rabbit (Sigma Aldrich) serum in $1 / 1$ ratio at $37^{\circ} \mathrm{C}$ water bath at 1 hour.

\section{Results}

The total amounts of polyclonal sera obtained after immunizations and storage conditions of Abs were given in Tables 3 and 4. Dilution rates of capturing and detecting polyclonal Abs for LPBE were determined as $1 / 8000$ for capturing (rabbit $A b$ ) and 1/2000 for detecting (guinea pig Ab) according to the checkerboard ELISA titration result. The final dilution rate was preferred more concentrated than the determined dilution rates for test reliability. Therefore, it was accepted as $1 / 5000$ for rabbit and 1/1000 for guinea pig Abs. Checkerboard titration test results of rabbit and guinea pig Abs were shown in Figures 1 and 2, respectively. Cross reaction results of sandwich ELISA between the FMDV serotypes and background control are shown in Figure 3.

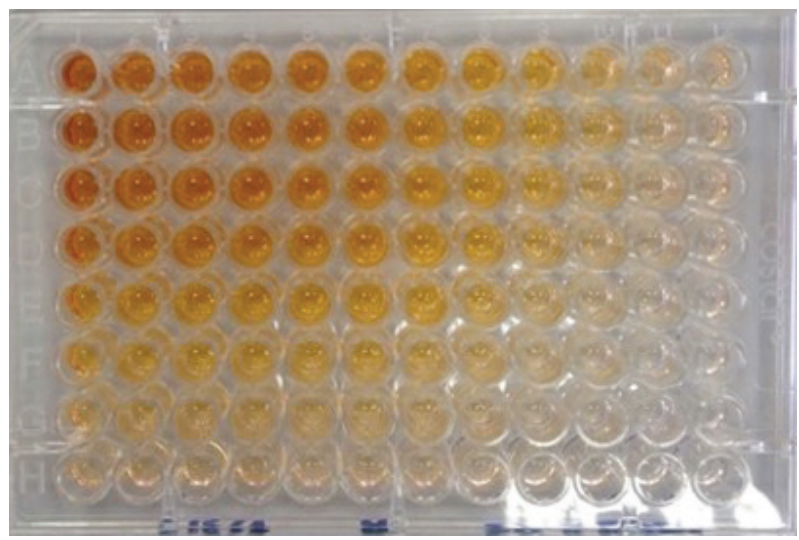

Figure 1. Rabbit or guinea pig-conjugate checkerboard study

Figure shows the colour change in the checkerboard titration. 
Figure 2. Checkerboard titration results of rabbit and guinea pig antibodies

\begin{tabular}{|c|c|c|c|c|c|c|c|c|c|c|c|}
\hline \multirow[t]{3}{*}{ FMDV OTUR 07} & 1 & 2 & 3 & 4 & 5 & 6 & 7 & 8 & 9 & 10 & \\
\hline & 2,7237 & 2,6896 & 2,6248 & 2,8141 & 2,3129 & 2,3037 & 2,1351 & 1,8398 & 1,6291 & 1,2471 & \\
\hline & 2,5377 & 2,4401 & 2,4297 & 2,3964 & 2,0838 & 1,9142 & 1,87 & 1,5643 & 1,5061 & 1,1767 & \\
\hline Rabbit Ab starting $1 / 125$ titer from-left to right line & 2,4204 & 2,3029 & 2,2513 & 2,2412 & 2,1107 & 1,9318 & 1,6086 & 1,5869 & 1,3921 & 1,2065 & guinea pig $A b: 1 / 2000$ \\
\hline FMDV $O$ ref virus $1 / 300$ dilution rate all wells & 2,6219 & 2,4715 & 2,4472 & 2,443 & 2,1828 & 2,0341 & 1,9805 & 1,6472 & 1,3758 & 1,1282 & rabbit $\mathrm{Ab}: 1 / 8000$ \\
\hline Guine pig $A b 1 / 62,5$ from top to bottom line & 2,193 & 2,0888 & 2,0477 & 2,1784 & 1,8122 & 1,7024 & 1,5423 & 1,4178 & 1,2325 & 1,0097 & \\
\hline \multirow[t]{3}{*}{ Conjugate commercial $1 / 2000$ constant dilution rate } & 2,3475 & 2,2444 & 2,1948 & 2,3154 & 1,8694 & 1,6769 & 1,6605 & 1,3536 & 1,218 & 1,0502 & \\
\hline & 2,4197 & 2,3939 & 2,2107 & 2,2319 & 1,9661 & 1,8513 & 1,6149 & 1,499 & 1,2646 & 1,1181 & \\
\hline & 1,5171 & 1,4272 & 1,5383 & 1,5823 & 1,3713 & 1,2178 & 1,0688 & 0,9098 & 0,8589 & 0,6145 & \\
\hline \multirow[t]{2}{*}{ FMDV A TUR11 } & 1 & 2 & 3 & 4 & 5 & 6 & 7 & 8 & 9 & 10 & \\
\hline & 3,496 & 3,4696 & 3,4352 & 3,4023 & 3,2599 & 3,034 & 2,9244 & 2,5713 & 2,3856 & 1,8473 & \\
\hline Rabbit Ab starting $1 / 125$ titer from-left to right line & 3,2486 & 3,1455 & 3,1078 & 2,9726 & 2,6283 & 2,5346 & 2,5098 & 2,2421 & 2,0164 & 1,5341 & guinea pig $A b: 1 / 2000$ \\
\hline FMDV A TUR11 ref virus $1 / 512$ dilution rate all wells & 2,9824 & 2,5289 & 2,7276 & 2,5554 & 2,3814 & 2,2423 & 2,291 & 1,9966 & 1,6551 & 1,3753 & rabbit $A b: 1 / 8000$ \\
\hline Guine pig $A b 1 / 62,5$ from top to bottom line & 2,9369 & 2,7527 & 2,7034 & 2,6224 & 2,3596 & 2,1811 & 1,9963 & 1,8557 & 1,6414 & 1,3465 & \\
\hline \multirow[t]{3}{*}{ Conjugate commercial $1 / 2000$ constant dilution rate } & 2,375 & 2,202 & 2,2 & 2,0042 & 1,712 & 1638 & 1,3927 & 1,366 & 1,2065 & 1,2272 & \\
\hline & 2,1507 & 1,9719 & 1,9653 & 1,8311 & 1,7072 & 1,3625 & 1,5581 & 1,4077 & 1,2581 & 1,0491 & \\
\hline & 1,8916 & 1,9007 & 1,9584 & 1,7909 & 1,4924 & 1,5185 & 1,4145 & 1,2476 & 1,1423 & 0,9267 & \\
\hline \multirow[t]{3}{*}{ FMDV A Nepal } & 1 & 2 & 3 & 4 & 5 & 6 & 7 & 8 & 9 & 10 & \\
\hline & 3,4309 & 3,2547 & 3,3423 & 3,0188 & 3,2508 & 2,7778 & 2,6438 & 2,128 & 1,5309 & 1,0183 & \\
\hline & 2,9283 & 2,8411 & 2,7925 & 2,6083 & 2,5159 & 2,2924 & 2,1909 & 1,6996 & 1,2638 & 0,8735 & \\
\hline Rabbit Ab starting $1 / 125$ titer from-left to right line & 2,5351 & 2,463 & 2,2434 & 2,0979 & 2,1244 & 1,9706 & 1,9158 & 1,6516 & 1,1876 & 0,8494 & guinea pig $A b: 1 / 2000$ \\
\hline FMDV A nepal virus $1 / 450$ dilution rate all wells & 2,7099 & 2,5791 & 2,5298 & 2,3238 & 2,3751 & 2,2624 & 2,1304 & 1,7635 & 1,1809 & 0,8089 & rabbit $\mathrm{Ab}: 1 / 8000$ \\
\hline Guine pig $A b 1 / 62,5$ from top to bottom line & 2,517 & 2,4102 & 2,522 & 2,2697 & 2,2823 & 2,1362 & 2,017 & 1,7482 & 1,3998 & 0,8921 & \\
\hline \multirow[t]{3}{*}{ Conjugate commercial $1 / 2000$ constant dilution rate } & 2,4524 & 2,4187 & 2,4147 & 2,3035 & 2,4478 & 2,2852 & 2,2124 & 1,7235 & 1,3592 & 0,9335 & \\
\hline & 2,9026 & 2,6331 & 2,4465 & 2,7438 & 2,6371 & 2,791 & 2,29 & 1,8017 & 1,456 & 0,9693 & \\
\hline & 2,7945 & 2,3328 & 2,2501 & 2,3465 & 2,3362 & 2,2266 & 2,0686 & 1,6111 & 1,1376 & 0,8266 & \\
\hline
\end{tabular}

Grey zones in the plates show the best optimal dilution curve of checkerboard titration.

\section{Discussion and Conclusion}

The rapid development of a unique diagnostic kit against FMDV is troublesome because of the continuous mutations in FMDVs and the risk of entrance for exotic FMDV strains from the neighboring countries of Turkey. It is necessary to produce Abs (polyclonal and/or monoclonal) for FMDV SP ELISA tests against each of newly emerged, genotypically crucial, exotic strains of FMDV just like the effort of a new primer-probe design for the molecular differentiation of novel FMDV with PCR. However, the period for the production of polyclonal Abs for FMDV serology takes a long time and laborious work (Parida 2009; Lavoria et al. 2012; Sala et al. 2018; Salem et al. 2019).

In the present study, the complete production and standardization process of Abs take approximately three months for each FMDV serotype. Besides, cross-reactions were detected among the FMDV serotypes in ELISA (Figure 3). Cross-reactions between the FMDV Abs is a possible problem due to the common sharing epitopes between the FMDV serotypes strains (Parida 2009; Bari et al. 2014; Ascoli and Aggeler 2018; Salem et al. 2019). Here, additional blocking steps were performed to alleviate cross-reactions. To mitigate high backgrounds, the dilution of polyclonal sera was also tried, and then the optimum dilution was determined for each $\mathrm{Ab}$ via checkerboard test to provide minimum background and cross-reactions.

Besides the time-consuming production and standardization process, animal usage for the production of polyclonal Abs is already contradictory to the 3R concept (Russell and Burch's 1959). Therefore, alternative tests or serological approaches were searched for FMDV-SP Abs detection in recent years. For this purpose, a monoclonal Ab-based antigen and $A b$ detection kits were developed by Brocchi (Brocchi 2012). However, Brocchi reported that imperfect FMDV type specificity and a different assay standardization for each FMDV serotype are some test limitations of these kits. In addition to monoclonal $\mathrm{Ab}$ based kits, a cocktail of polyclonal or monoclonal Abs usage, chimeric antibodies, recombinant $A b$ production, virus-like particles, or recombinant proteins have also been studied (Ko et al. 2009; Yang et al. 2017; Cao et al. 2018, Ran et al. 2019).

In conclusion, routine tests for detection of FMDV-SP antibody are still based on polyclonal and monoclonal Abs production. However, there is not adequate study about polyclonal $\mathrm{Ab}$ production 
and standardization. The present study was carried out primarily to focus on polyclonal Ab production steps in general. Polyclonal Abs were produced against Turkey FMDV strains and standardized for LPBE test. A further study needs to determine the purity of Abs via Western Blotting

Figure3. Background and cross-reaction control in the optimal dilution of antibodies.

\begin{tabular}{|c|c|c|c|c|c|c|c|c|c|c|c|c|c|c|}
\hline & & & & & & & & & & & & & & Cross control \\
\hline \multirow[t]{2}{*}{ FMDV OTUR 07} & & 1 & 2 & 3 & 4 & 5 & 6 & 7 & 8 & 9 & 10 & 11 & 12 & virus \\
\hline & $A$ & 2,3291 & 2,3985 & 2,2309 & 2,2056 & 2,0094 & 1,9036 & 1,7875 & 1,6729 & 1,4808 & 1,1906 & 0,0693 & 0,0793 & OTUR07 \\
\hline \multirow{2}{*}{$\begin{array}{l}\text { 1/5000 Rabbit antibody-1/1000 } \\
\text { guinea pig antibody }\end{array}$} & $C$ & 0,2424 & 0,253 & 0,2606 & 0,2693 & 0,2438 & 0,2045 & 0,1672 & 0,1515 & 0,1232 & 0,1026 & 0,0632 & 0,0687 & ATUR11 \\
\hline & $\mathrm{D}$ & 0,4306 & 0,3677 & 0,3045 & 0,3013 & 0,226 & 0,2145 & 0,1662 & 0,1362 & 0,1124 & 0,0974 & 0,0619 & 0,0718 & ANEPAL \\
\hline \multirow[t]{2}{*}{ FMDV A TUR11 } & & 1 & 2 & 3 & 4 & 5 & 6 & 7 & 8 & 9 & 10 & background & background & virus \\
\hline & A & 1,5172 & 1,8986 & 1,927 & 1,7962 & 1,8931 & 1,9956 & 1,7776 & 1,3981 & 1,014 & 0,7022 & 0,0771 & 0,0792 & ATUR11 \\
\hline \multirow{3}{*}{$\begin{array}{l}\text { 1/5000 Rabbit antibody- } 1 / 1000 \\
\text { guinea pig antibody }\end{array}$} & B & 0,381 & 0,2381 & 0,1841 & 0,1386 & 0,1145 & 0,1092 & 0,1052 & 0,116 & 0,1047 & 0,1152 & 0,0778 & 0,0821 & ATUR11 \\
\hline & $C$ & 0,3591 & 0,3622 & 0,3432 & 0,3082 & 0,2828 & 0,3062 & 0,2917 & 0,276 & 0,2545 & 0,2229 & 0,0825 & 0,0908 & OTUR07 \\
\hline & D & 0,265 & 0,2614 & 0,2715 & 0,235 & 0,2207 & 0,1904 & 0,1772 & 0,1592 & 0,1478 & 0,1313 & 0,0943 & 0,1009 & A NEPAL \\
\hline \multirow[t]{2}{*}{ FMDV A Nepal } & & 1 & 2 & 3 & 4 & 5 & 6 & 7 & 8 & 9 & 10 & background & background & virus \\
\hline & A & 2,3538 & 2,285 & 2,347 & 1,9889 & 1,9626 & 1,8389 & 1,7156 & 1,5777 & 1,2303 & 0,819 & 0,0881 & 0,0833 & A NEPAL \\
\hline guinea pig antibody & $C$ & 0,2451 & 0,2386 & 0,288 & 0,2785 & 0,2621 & 0,2423 & 0,2506 & 0,1865 & 0,1872 & 0,1465 & 0,0813 & 0,0786 & OTUR07 \\
\hline & $\mathrm{D}$ & 0,1418 & 0,1686 & 0,179 & 0,171 & 0,1631 & 0,1513 & 0,1493 & 0,1146 & 0,108 & 0,0953 & 0,0877 & 0,0806 & ATUR11 \\
\hline
\end{tabular}

Plates were coated with optimal dilution (well A-D) of capturing antibodies according to the final checkerboard dilution of each sero- type of FMDV antibodies (1/5000). Then, to check cross-reactions of FMDV OTUR07 with the other FMDV strains (ANepal and ATUR11), optimal dilution of FMDV OTUR07 was added to (well A-B). After that, optimal dilutions of FMDV A TUR11 and FMDV ANepal were added to wells C and D, respectively. Similar to the OTUR07 cross reaction study, the same steps were performed to detect cross-reactions of FMDV ATUR11 and ANepal with other FMDV serotypes. 11-12 wells were left as background.

Ethical statement: Ethics committee approval for the immunisation of guinea pigs used in the research was given by the local ethics committee of the Foot and Mouth Disease (SAP) Institute, Turkish Ministry of Agriculture and Rural Affairs (decision no: 2015/10). Ethics committee approval for the immunisation of rabbits used in the research was given by the local ethics committee of Veterinary Control Central Research Institute, Turkish Ministry of Agriculture and Rural Affairs (Decision no: 2015/09).

Acknowledgements: The author is grateful to Dr. Bern Haas for his kind support for the blocking procedure of ELISA and thanks to Serology Laboratory technicians; Yavuz Yıldırım and Yusuf Demir for their laboratory effort. Faruk Yıldız, for his technical help in the 146S test. This study was supported by Foot-and-Mouth Disease Institute, SAP, Ankara.

Conflict of Interest: There is no conflict of interest.

\section{References}

Anonymus.https://www.oie.int/fileadmin/Home/eng/Health standards/tahm/3.01.08FMD.pdf (Accessed: 10.08.2019)

Ascoli AG and Aggeler B. (2018) Overlooked benefits of using polyclonal antibodies. Biotechniques. 65, 127- 136. doi: 10.2144/btn-2018-0065.
Bari FD, Parida S, Tekleghiorghis T, Dekker A, Sangula A, Reeve R, Haydon DT, Paton DJ, Mahapatra M (2014) Genetic and antigenic characterization of serotype A FMD viruses from East Africa to select new vaccine strains. Vaccine. 32, 57945800.

Barteling SJ and Meloen RH. (1974) A simple method for the quantification of $140 \mathrm{~S}$ particles of foot and mouth disease virus. Arch Ges Virusforsch 45, 362-364

Brocchi E. (2012). New ELISAs for FMD Diagnosis, EUFMD Open Session, October 29-31-Jerez, Spain.

Cao Y, Zhou W, Xing X, Zang J, Fu Y, Li K, Sun P, Li P, Bai X, Ma X, Bao H, Li D, Chen Y, Lu Z, Liu Z. (2018) Indirect ELISA using a multi-epitope recombinant protein to detect antibodies against foot-and-mouth disease virus serotype $O$ in pigs. $J$ Virol Methods. 262, 26-31. doi: 10.1016/j.jviromet.2018.09.008

Crowther JR. (2001). ELISA guidebook, second edition Humana Press, UK, p:79

Diaz-San Segundo F, Medina GN, Stenfeldt C, Arzt J, de Los Santos T. (2017) Foot-and-mouth disease vaccines. Vet Microbiol. 206, 102-112. doi: 10.1016/j.vetmic.2016.12.018.

Ferris NP, Donaldson AJ. (1984) Serological response of guinea pigs to inactivated $146 \mathrm{~S}$ antigens of FMDV after single or repeated inoculations. Rev Sci Tech OIE. 3, 563-574.

Fry EE, Stuart DI, Rowlands DJ. (2005) The structure of FMDV. Current Topics Microbiol Immunol. 288, 71-101. doi: 10.1007/3-540-27109-0_4.

Hamblin C, Barnett ITR, Hedger RS. (1986) A new enzyme-linked immunosorbent assay (ELISA) for the detection of antibodies against foot-and-mouth disease virus I. Development and method of ELISA. J Immunol Methods. 93, 11-121. doi: 10.1016/0022-1759(86)90441-2. 
Harlow E and Lane D. (1988) Antibodies, A laboratory manual. Second edition, CSHL Press, USA, p: 60

Have P, Lei JC, Thiesen K. (1984) An enzyme linked immune absorbent assay for the primary diagnosis of FMD. Characterization and comparison with complement fixation. Acta Vet Scand. 25, 280-296.

Jamal SM, Belsham, GJ. (2013) Foot-and-mouth disease: past, present and future. Vet Res. 44, 116. doi: 10.1186/1297-971644-116.

Ko YJ, Jeoung HY, Lee HS, Chang BS, Hong S-M, Heo E-J, Lee K-N, Joo H-D, Kim SM, Park J-H, Kweon C-H. (2009) A recombinant protein based ELISA for detecting antibodies to foot-andmouth disease virus serotype Asia J Virol Methods 159, 112118.doi: DOI: 10.1016/j.jviromet.2009.03.011

Lavoria MÁ, Di-Giacomo S, Bucofusco D, Franco-Mahecha OL, Perez-Filgueira DM, Capozzo AV. (2012) Avidity and subtyping of specific antibodies applied to the indirect assessment of heterologous protection against Foot-and-Mouth Disease Virus in cattle. Vaccine. 30(48), 6845-50. doi:110.1186/12979716-44-116.

Leenaars M and Hendriksen CF. (2005) Critical steps in the production of polyclonal and monoclonal antibodies: Evaluation and recommendations. ILAR Journal. 46, 269-79. doi: 10.1093/ilar.

Leenaars PPA, Hendriksen CFM, Leeuw WA, Carat F, Delehaut P, Fischer F, Halder M, Hanly WC, Hartinger J, Hau J, Lindblad EB, Nicklas B, Outschoorn M, Stewart-Tall DE. (1999) The production of polyclonal antibodies in laboratory animals. ATLA. 27, 79-102. doi: 10.1177/ATLA.1999.

Lipman NS, Jackson LR, Trudel LJ, Weis-Garcia F. (2005) Monoclonal versus polyclonal antibodies: distinguish characteristics, applications, and information resources. ILAR Journal. 46, 258-268. doi: https://doi.org/10.1093/ ilar.46.3.258

Low D, O'Leary R, Pujar NS. (2006) Future of antibody purification. J Chrom 848, 48-63.
Parida S. (2009) Vaccination against FMDV strategies and effectiveness. Expert Rev Vaccines. 8(3), 347-365. doi:10.1586/14760584.8.3.347.

Ran X, Yang Z, Bai M, Zhang Y, Wen X, Guo H, Sun Ş. (2019) Development and validation of a competitive ELISA based on bacterium-original virus-like particles of serotype $\mathrm{O}$ footand-mouth disease virus for detecting serum antibodies. Appl Microbiol Biotech. 103, 3015-3024. doi:10.1007/s00253019-09680-8.

Russell and Burch's, 3Rs concept (Refine-Reduce-Replace, Russell W. (1959). The principles of humane experimental technique. London.

Sala JM, Trotta MV, Mansilla FC, Filgueira MP, Gaston S, Capozzo A. (2018) Alternatives for the serological assessment of footand-mouth disease vaccine immunity in buffaloes (Bubalus bubalis) J App Anim Res. 46, 451-458. https://doi.org/10.108 0/09712119.2017.1335641

Salem R, El-Kholy A, Omar AO, Abu-el Naga El, Osman G. (2019) Construction, expression and evolution of recombinant VP2 protein for serotype independent detection of FMDV seropositive animals in Egypt. Sci Report. 9, 10135. doi: 10.1038/s41598-019-46596-9

Sorensen KJ, Madsen KG, Madsen ES, Salt JS, Nqindi J, Mackay DKJ. (1998) Differentiation of infection from vaccination in foot-and-mouth disease by the detection of antibodies to the non- structural proteins $3 D, 3 A B$ and $3 A B C$ in ELISA using antigens expressed in baculovirus. Arch Virol. 143, 14611476. doi: $10.1007 / \mathrm{s} 007050050390$

Voskuil JLA. (2014) Commercial antibodies and their validation. F1000 Research 3, 232. doi: https://doi.org/10.12688/ f1000research.4966.2

Yang $M$, Xu W, Bitner $H$, Jacquelyn $H$, Vosloo W, Goolia M, Lusansky D, Nfon C. (2017) Generation of MAbs to footand-mouth disease virus serotype $A$ and application in a competitive ELISA for serodiagnosis. Virol J. 195(13), 195.

Zumdahl SS and De Coste DJ. (2009). Introduction Chemistry. Nineth edition Cengage Learning, USA, p: 34 